\title{
Mechanisms of overburden deformation associated with the emplacement of the Tulipan sill, mid-Norwegian margin
}

\author{
Tobias Schmiedel ${ }^{1}$, Sigurd Kjoberg ${ }^{2}$, Sverre Planke $^{3}$, Craig Magee $^{4}$, Olivier Galland ${ }^{1}$, Nick Schofield ${ }^{5}$, \\ Christopher A.-L. Jackson ${ }^{4}$, and Dougal A. Jerram ${ }^{6}$
}

\begin{abstract}
The emplacement of igneous intrusions into sedimentary basins mechanically deforms the host rocks and causes hydrocarbon maturation. Existing models of host-rock deformation are investigated using high-quality 3D seismic and industry well data in the western Møre Basin offshore mid-Norway. The models include synemplacement (e.g., elastic bending-related active uplift and volume reduction of metamorphic aureoles) and postemplacement (e.g., differential compaction) mechanisms. We use the seismic interpretations of five horizons in the Cretaceous-Paleogene sequence (Springar, Tang, and Tare Formations) to analyze the host rock deformation induced by the emplacement of the underlying saucer-shaped Tulipan sill. The results show that the sill, emplaced between 55.8 and $54.9 \mathrm{Ma}$, is responsible for the overlying dome structure observed in the seismic data. Isochron maps of the deformed sediments, as well as deformation of the younger postemplacement sediments, document a good match between the spatial distribution of the dome and the periphery of the sill. The thickness $t$ of the Tulipan is less than $100 \mathrm{~m}$, whereas the amplitude $f$ of the overlying dome ranges between 30 and $70 \mathrm{~m}$. Spectral decomposition maps highlight the distribution of fractures in the upper part of the dome. These fractures are observed in between hydrothermal vent complexes in the outer parts of the dome structure. The 3D seismic horizon interpretation and volume rendering visualization of the Tulipan sill reveal fingers and an overall saucer-shaped geometry. We conclude that a combination of different mechanisms of overburden deformation, including (1) elastic bending, (2) shear failure, and (3) differential compaction, is responsible for the synemplacement formation and the postemplacement modification of the observed dome structure in the Tulipan area.
\end{abstract}

\section{Introduction}

Volcanic basins contain significant volumes of igneous rocks (Planke et al., 2015; Jerram and Bryan, 2017), e.g., the Karoo Basin (Svensen et al., 2012) and midNorwegian margin (Planke et al., 2005). In addition, they are explored for hydrocarbons all over the world (e.g., Senger et al., forthcoming), onshore and offshore, e.g., the Rockall Basin (e.g., Magee et al., 2014), the Faroe-Shetland Basin (e.g., Smallwood and Maresh, 2002), the Møre and Vøring Basins (e.g., Planke et al., 2005; Cartwright and Hansen, 2006), and the Neuquén Basin (e.g., Kay et al., 2006). The magma plumbing systems in these basins are primarily dominated by interconnected networks of sill intrusions, the emplacement of which can significantly deform the host rock and influence petroleum system development (Kontorovich et al., 1997; Thomson and Hutton, 2004; Cartwright and Hansen, 2006; de Saint-Blanquat et al., 2006; Morgan et al., 2008; Galerne et al., 2011; Schofield et al., 2015; Magee et al., 2016; Wilson et al., 2016). For example, numerous studies have demonstrated that sill intrusions may (1) locally heat and mature organic matter within the host rock, generating oil and/or gas (e.g., Rodriguez Monreal et al., 2009), (2) be associated with

\footnotetext{
${ }^{1}$ University of Oslo, Physics of Geological Processes (PGP), Department of Geosciences, Oslo, Norway. E-mail: tobias.schmiedel@geo.uio.no; olivier.galland@geo.uio.no.

${ }^{2}$ University of Oslo, Centre for Earth Evolution and Dynamics (CEED), Department of Geosciences, Oslo, Norway. E-mail: sigurd.kjoberg@geo .uio.no.

${ }^{3}$ University of Oslo, Centre for Earth Evolution and Dynamics (CEED), Department of Geosciences, Oslo, Norway and Volcanic Basin Petroleum Research AS (VBPR), Oslo, Norway. E-mail: planke@vbpr.no.

${ }^{4}$ Imperial College London, Basins Research Group, Department of Earth Science and Engineering, London, UK. E-mail: c.magee@imperial.ac.uk; c.jackson@imperial.ac.uk.

${ }^{5}$ University of Aberdeen, Department of Geology and Petroleum Geology, School of Geosciences, Aberdeen, UK. E-mail: n.schofield@abdn.ac.uk.

${ }^{6}$ University of Oslo, Centre for Earth Evolution and Dynamics (CEED), Department of Geosciences, Oslo, Norway and DougalEARTH Ltd., Solihull, UK. E-mail: dougal@dougalearth.com.

Manuscript received by the Editor 28 September 2016; revised manuscript received 13 December 2016; published online 3 April 2017; corrected version published online 7 April 2017. This paper appears in Interpretation, Vol. 5, No. 3 (August 2017); p. SK23-SK38, 8 FIGS.

http://dx.doi.org/10.1190/INT-2016-0155.1. @ 2017 Society of Exploration Geophysicists and American Association of Petroleum Geologists. All rights reserved.
} 
overlying dome structures that can be described as four-way dip closures (Hansen and Cartwright, 2006; Jackson et al., 2013; Magee et al., 2014, 2015), and (3) promote the development of local intense fracture networks that locally increase host rock permeability (Witte et al., 2012; Agirrezabala, 2015; Senger et al., 2015). A robust understanding of the mechanics of magma emplacement in volcanic basins is therefore required to derisk hydrocarbon exploration in volcanic basins (Potter and Konnerup-Madsen, 2003; Schutter, 2003a, 2003b).

In this study, we focus on the mechanisms that control the growth of domes, often called forced folds (e.g., Stearns, 1978; Magee et al., 2013), associated with igneous sills. These domes can represent structural traps (i.e., four-way dip closures) or create and deform stratigraphic traps (e.g., onlap of reservoir rocks and deflection of channels influencing the distribution of reservoir rocks for hydrocarbons; Schutter, 2003a; Delpino et al., 2014). In recent years, distinct mechanisms controlling the formation of sill-associated doming have been proposed. The most common mechanism involves synemplacement uplift accommodating sill intrusion (e.g., Pollard and Johnson, 1973; Roman-Berdiel et al., 1995; Malthe-Sørenssen et al., 2004; Hansen and Cartwright, 2006; Kavanagh et al., 2006; Menand, 2008; Bunger and Cruden, 2011; Galerne et al., 2011; Galland, 2012; Galland et al., 2014, 2015). These models typically assume that uplift occurs via elastic bending, and sometimes failure, of the overburden, causing forced folding and fracturing due to the intrusion. However, field observations, seismic studies, and recent 3D laboratory models show that substantial synemplacement inelastic (elastoplastic) deformation, such as local compaction and fluidization, can also affect the growth of these domes (e.g., Cosgrove and Hillier, 1999; Hansen and Cartwright, 2006; Schofield et al., 2010, 2012a, 2014; Magee et al., 2013). In addition to the synemplacement mechanisms, seismic data indicate that postemplacement differential compaction may also play a role in forming or modifying dome structures above sills (e.g., Einsele et al., 1980; Cosgrove and Hillier, 1999; Hansen and Cartwright, 2006; Agirrezabala, 2015).

However, the extent to which the interplay between syn- and postemplacement mechanisms controls the final shape and structure of domes associated with igneous intrusions remains poorly constrained. This uncertainty typically emanates from the methods applied to study these systems. For example, structural field observations can provide small, detailed snapshots of dome structures overlying intrusions and associated fault and fracture systems, but they cannot provide a complete spatial understanding due to incomplete outcropping conditions (e.g., Henry Mts; Wilson et al., 2016). The $2 \mathrm{D}$ seismic reflection profiles are also too incomplete to fully describe complex 3D structures (e.g., Planke et al., 2000; Berndt et al., 2001; Jackson et al., 2013; Zhao et al., 2014). Therefore, high-quality 3D seismic data are essential to study intrusion-induced over- burden deformation in 3D (Bell and Butcher, 2002; Smallwood and Maresh, 2002; Trude et al., 2003; Polteau et al., 2008; Magee et al., 2015; Planke et al., 2015). In this paper, we show how the detailed analysis of high-quality $3 \mathrm{D}$ seismic data can be used to test and constrain the relevance of mechanical models of dome growth accommodating the emplacement of igneous sills. We highlight the contribution of syn- and postemplacement mechanisms of overburden deformation by using detailed mapped horizons from 3D seismic reflections, thickness maps, and the application of various seismic attributes.

\section{Mechanisms of overburden deformation}

A range of different models derived from field observations and seismic imaging have been proposed to explain overburden deformation above sills, particularly dome-shaped structures.

\section{Synemplacement processes}

Classic models of doming involve overburden uplift in response to elastic bending above an intruding sill or laccolith (Figure 1a) (Gilbert, 1877; Pollard and Johnson, 1973; Dixon and Simpson, 1987; Goulty and Schofield, 2008; Bunger and Cruden, 2011; Galland and Scheibert, 2013). In these models, doming occurs during the sill emplacement, and the dome geometry is directly controlled by that of the underlying intrusion (e.g., Gilbert, 1877; Pollard and Johnson, 1973; Corry, 1988; Goulty and Schofield, 2008; Galland and Scheibert, 2013). Therefore, the dome amplitude $f$ equals the sill thickness $t$ (Figure 1a) (Pollard and Johnson, 1973; Dixon and Simpson, 1987; Goulty and Schofield, 2008; Bunger and Cruden, 2011; Galland and Scheibert, 2013); $f$ and $t$ can be used as a proxy for the volume of the dome and intrusion, respectively. This active doming is often referred to as forced folding (e.g., du Toit, 1920; Stearns, 1978; Trude et al., 2003). Forced folding typically produces a positive topographic structure at the contemporaneous surface, such that sediments deposited during sill emplacement will onlap onto the topographic or bathymetric high (e.g., Trude et al., 2003; Schofield et al., 2015; Magee et al., 2016). The observation of these onlap features in seismic data provides a method of dating the intrusion emplacement if sufficient borehole data are available to constrain the age of sedimentary horizons (Trude et al., 2003).

Elastic bending produces complex stress distributions in the overburden, resulting in outer-arc stretching and inner-arc compression (Timoshenko and Woinowsky-Krieger, 1959; Ramsay, 1967; Pollard and Johnson, 1973). This outer-arc stretching can lead to thinning of the uppermost layers of the dome (Ramsay, 1967). When the stresses generated in response to elastic bending exceed the strength of the overburden rocks, failure occurs and characteristic fracture patterns develop. These fracture pattern can be classified into four main types depending on their location in the overburden (Figure 1b): (1) circumferential, tensile fractures at the surface coincident with the area of the largest convex 
curvature above the sill edges (e.g., Pollard and Johnson, 1973; Bunger and Cruden, 2011; Galland et al., 2016), (2) radial tensile fractures (mode I) and/or normal faults (mode II) due to an extensional regime (i.e., outer-arc stretching) in the central part of the dome structure (Hansen and Cartwright, 2006; Magee et al., 2013; Galland et al., 2016), (3) dilational fractures near the peripheral hinge of the dome, close to the intrusion tips, which progress toward the surface (Pollard and Johnson, 1973; Menand, 2008; Thomson and Schofield, 2008; Galland and Scheibert, 2013; Agirrezabala, 2015), and (4) shear fractures resulting from differential uplift at the dome edge (de Saint-Blanquat et al., 2006; Hansen and Cartwright, 2006; Wilson et al., 2016).

Although elastic bending promotes roof uplift, other mechanisms can affect the overall geometry of the dome structure above the intrusion. For example, pore fluid expulsion within the thermal and/or structural aureole of the intrusion can lead to a significant volume reduction of the host rock (Figure 1c) (Einsele et al., 1980; Morgan et al., 2008; Schofield et al., 2010, 2012a, 2014; Jackson et al., 2013; Magee et al., 2013). This volume reduction resulting from a decreased porosity reduces the effect of active mechanical doming due to the emplacement of the intrusion. Therefore, the amplitude of the dome $f$ is expected to be less than the sill thickness $t$, implying that the overlying host rock succession thins across the sill (Figure 1c).

\section{Postemplacement process}

Variations in the load of postemplacement sedimentation can induce a variable subsidence of the overburden due to differential compaction (Figure 1d) (e.g., Cosgrove and Hillier, 1999; Hansen and Cartwright, 2006). In particular, following sill intrusion, the load due to postemplacement sedimentation triggers compaction of the underlying rocks. Because intrusions are virtually incompressible with respect to the surrounding sedimentary rocks, and therefore do not compact, a dome structure may develop (Figure 1d) (e.g., Cosgrove and Hillier, 1999; Hansen and Cartwright, 2006). In addition to generating new folds, this differential compaction process can enhance the amplitude $f$ of a preexisting dome due to the emplacement of the intrusion, such that $f$ becomes larger than the sill thickness $t$ (Figure 1d); i.e., the domed sequence is also expected to be thicker above the sill than outside the sill (Figure 1d).

To summarize, these models of synand postintrusion emplacement mechanisms are associated with distinct characteristic structures and features. To test the relevance of each model, we will test the occurrence, or not, of these structures and features in the Tulipan prospect case study, Møre Basin, mid-Norwegian continental margin.

\section{Geologic framework}

Over the past three decades, massive sill complexes with an extent of at least $80,000 \mathrm{~km}^{2}$ have been imaged in the Møre and Vøring Basins, offshore Norway by 2D and 3D seismic reflection data (e.g., Berndt et al., 2001; Planke et al., 2005). Positioned on the mid-Norwegian margin, the Møre Basin represents an example of a rifted volcanic margin (Planke et al., 2005; Abdelmalak et al., 2015). The outline of the Møre Basin is defined by the base unconformity of the up to $6 \mathrm{~km}$ thick Cretaceous sedimentary basin infill (Figure 2a) (Brekke, 2000; Faleide et al., 2010). The development of the basin occurred during Late Jurassic-Early Cretaceous rifting of the Norwegian continental margin (Brekke, 2000). Late Paleocene-Early Eocene rifting associated with the opening of the North Atlantic led to the emplacement of a significant volume of igneous material (e.g., Abdelmalak et al., 2015); including the emplacement of the Tulipan saucer-shaped sill, which forms the focus of this study. The intrusion hosting sedimentary infill is composed of mainly claystone, with interbedded sand- a) Elastic bending $(f=t)$

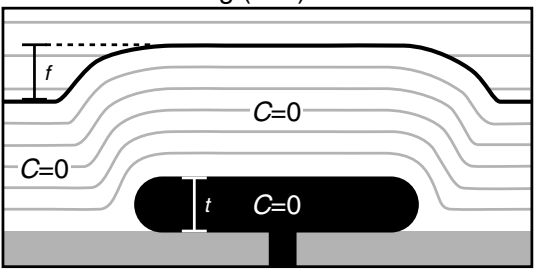

c) Aureole/volume reduction effect $(f<t)$

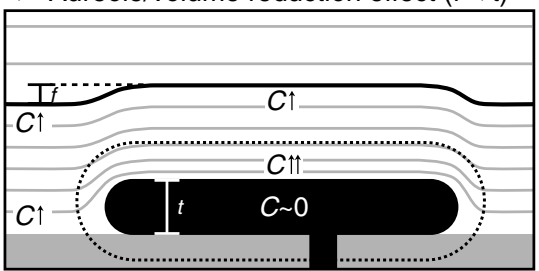

W high load $\Downarrow$ normal load $\Uparrow$ high compaction(C) $\uparrow$ normal compaction(C) $t$ intrusion thickness $f$ fold amplitude b) Fracture pattern

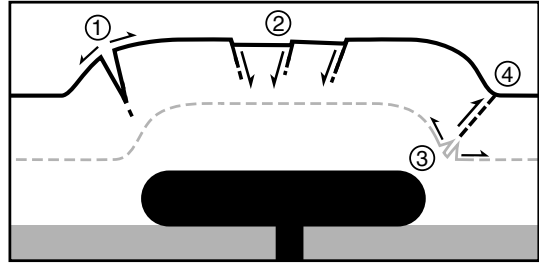

d) Differential compaction $(f>t)$

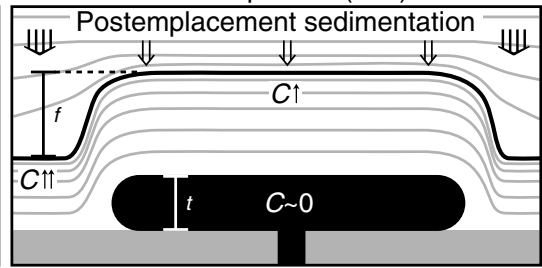

Figure 1. Schematic diagrams showing mechanisms of overburden deformation associated with intrusion emplacement. (a) The simple elastic model envisages the formation of a dome structure (forced fold) above an intrusion (e.g., Pollard and Johnson, 1973; Galland and Scheibert, 2013). (b) Four fracture types related to elastic overburden deformation: (1) circumferential, tensile fractures coincident with the area of the largest convex curvature of the dome (e.g., Pollard and Johnson, 1973; Bunger and Cruden, 2011; Galland et al., 2016), (2) radial tensile fractures (mode I) and/or normal faults (mode II) due to outer-arc stretching (Hansen and Cartwright, 2006; Magee et al., 2013; Galland et al., 2016), (3) dilational fractures progressing toward the surface (Pollard and Johnson, 1973; Menand, 2008; Thomson and Schofield, 2008; Galland and Scheibert, 2013; Agirrezabala, 2015), and (4) shear fractures resulting from differential uplift (de Saint-Blanquat et al., 2006; Hansen and Cartwright, 2006; Wilson et al., 2016). (c) Model of volume reduction, i.e., porosity decrease, affected by the aureole of the intrusion (e.g., Hansen and Cartwright, 2006; Jackson et al., 2013). (d) Differential compaction model envisages the formation and/or enhancement of a dome structure associated with an intrusion under the load of postemplacement sedimentation (e.g., Cosgrove and Hillier, 1999; Hansen and Cartwright, 2006). 
stone and sporadic carbonate intercalations (e.g., Dalland et al., 1988; Berndt et al., 2001; Planke et al., 2005).

The oldest stratigraphic unit in the area of interest is the Late Cretaceous Springar Formation, which consists mainly of claystone with carbonate intercalations. The uppermost sequence of the Springar Formation contains a prominent carbonate-cemented layer that corresponds to the lowermost horizon interpreted in this study (Figure 3). The base of this carbonate layer, subsequently referred to as Base Carbonate, corresponds to a high-amplitude positive reflection on the seismic data (Figures 3, 4 , and 5). Other horizons interpreted in this study include the Top Danian and HV4 (HV nomenclature adopted from Kjoberg et al., 2017), which are both contained in the Early Paleogene Tang Formation (Figure 3). The lower Tang Formation (Top Danian to Base Carbonate) is composed of a sandstone succession, which proved to be a reservoir rock in the Tulipan prospect, as highlighted by a gas discovery well (6302/6-1; Figure 2). The rest of the Tang Formation consists of dark gray claystone successions (Figure 3) (Dalland et al., 1988). New highly resolved biostratigraphic results from Kjoberg et al. (2017) highlight the uncertainty of the HV3 and HV1 regarding their affiliation to the Tang or Tare Formation (Figure 3). Above the Tang Formation, we interpreted the top of the Eocene Tare Formation (Top Tare; Figure 3) and the top of the Neogene Kai Formation (Top Kai; Figure 3). The complete stratigraphic description of the Tulipan prospect can be found in Kjoberg et al. (2017). The area of interest is located beyond the eastern limit of Paleogene basalts that cover the northwestern border of the Møre Basin (Figure 2) (e.g., Brekke, 2000; Berndt et al., 2001).

\section{Data and methods}

This study uses a full-stack, time-migrated, zerophase 3D seismic data set (Statoil 3D cube ST0105) that
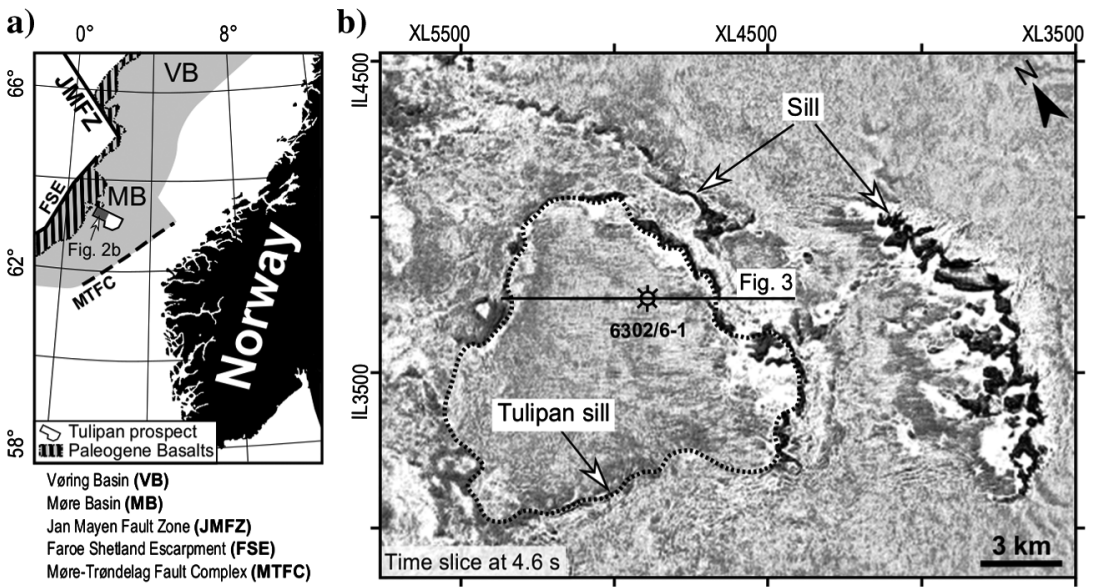

Figure 2. Location maps. (a) Position of the 3D seismic survey containing the Tulipan prospect in the Møre Basin on the Norwegian continental shelf with respect to the Norwegian mainland. Outline of the Paleogene basalts after Berndt et al. (2001). (b) Seismic reflection time slice showing the main igneous complexes identified in the study area. The Tulipan sill is indicated (dashed line) in addition to the location of well 6302/6-1. was processed in 2001 and covers the Tulipan prospect in the western part of the Møre Basin (Figure 2). The complete 3D survey covers an area of $1610 \mathrm{~km}^{2}$, has a line spacing of $12.5 \mathrm{~m}$, and was recorded to a depth of $7 \mathrm{~s}$ two-way traveltime (TWT). We focus on the northern approximately $450 \mathrm{~km}^{2}$ of the seismic cube containing the well 6302/6-1 (Figure 2). The 3D seismic data are displayed with a reverse polarity (i.e., a downward increase in acoustic impedance correlates to negative or blue reflections). In the time interval of interest (4.6-4.8 s TWT), the seismic data have a dominant frequency of $15-20 \mathrm{~Hz}$. The range for the thickness of the sill was calculated using the dominant frequency in the area of the sill intrusion $(15 \mathrm{~Hz})$ and velocity $V_{P} 5500 \mathrm{~m} / \mathrm{s}$, with an assumed error of $\pm 10 \%$ (Planke et al., 2005; Jackson et al., 2013; Magee et al., 2015). This suggests that sills with thicknesses below the resolution limit of $\lambda / 4$ (approximately $92 \mathrm{~m} \pm 10 \%$ ) will appear as tuned reflection packages, whereas those below the detection limit $\lambda / 30$ (approximately $12 \mathrm{~m} \pm 10 \%$ ) will not be identified (Planke et al., 2005; Jackson et al., 2013).

Data from borehole 6302/6-1 were used to constrain the lithology, geophysical properties, and age of the strata in the interval of interest (see also Kjoberg et al., 2017). The well extends to a depth of $4234 \mathrm{~m}$ (below rotary kelly bushing), a total length of $15.7 \mathrm{~m}$ was cored between 3903 and $3942 \mathrm{~m}$ in the Danian sandstones (Tang Formation), and cutting samples were taken in the interval of 1975-4230 m. Conventional borehole wireline logs and a check-shot vertical seismic profile (VSP) time-depth curve, in combination with the core/cutting samples, were used to develop a simple layered velocity model based on the interval velocities $V_{P_{\text {int }}}$ to convert the key horizons from time to depth (Figure 3). The continuity of the reflection strength and their (sub-) horizontal appearance in our 3D seismic data show little evidence of lateral variations in the geology that would produce velocity anomalies. Therefore, we consider the effects of horizontal velocity variations in the data to be minimal in the study area, and we use the velocity model constrained from the well data as the basis for this study (Figure 3). This information combined with the 3D seismic data were used to interpret five key horizons (5-15 line interval inline/crossline) in the sedimentary strata above the intrusion (Figures 3 and 4). The 3D volume visualization techniques (e.g., opacity rendering; Supplemental Figures 1, 2, and 3 can be accessed through the following links: s1.eps, s2.eps, and s3.eps) and different surface and volume attributes (e.g., rootmean-square amplitude, coherence, and spectral decomposition) were used to extract additional characteristics of the interpreted reflections in the sedimentary overburden of the Tulipan sill (Planke et al., 2015). 
The interpretation of sills in the seismic data was performed according to their reflection properties, with laterally discontinuous, strata-discordant, high-amplitude anomalies considered to represent intrusions (Smallwood and Maresh, 2002; Polteau et al., 2008;
Thomson and Schofield, 2008; Jackson et al., 2013; Magee et al., 2014; Planke et al., 2015). At the location of the Tulipan sill, constrained by Polteau et al. (2008), the seismic data display a high-amplitude reflection (Figures 5 and 4). We define the top of the Tulipan sill as

a)

b)
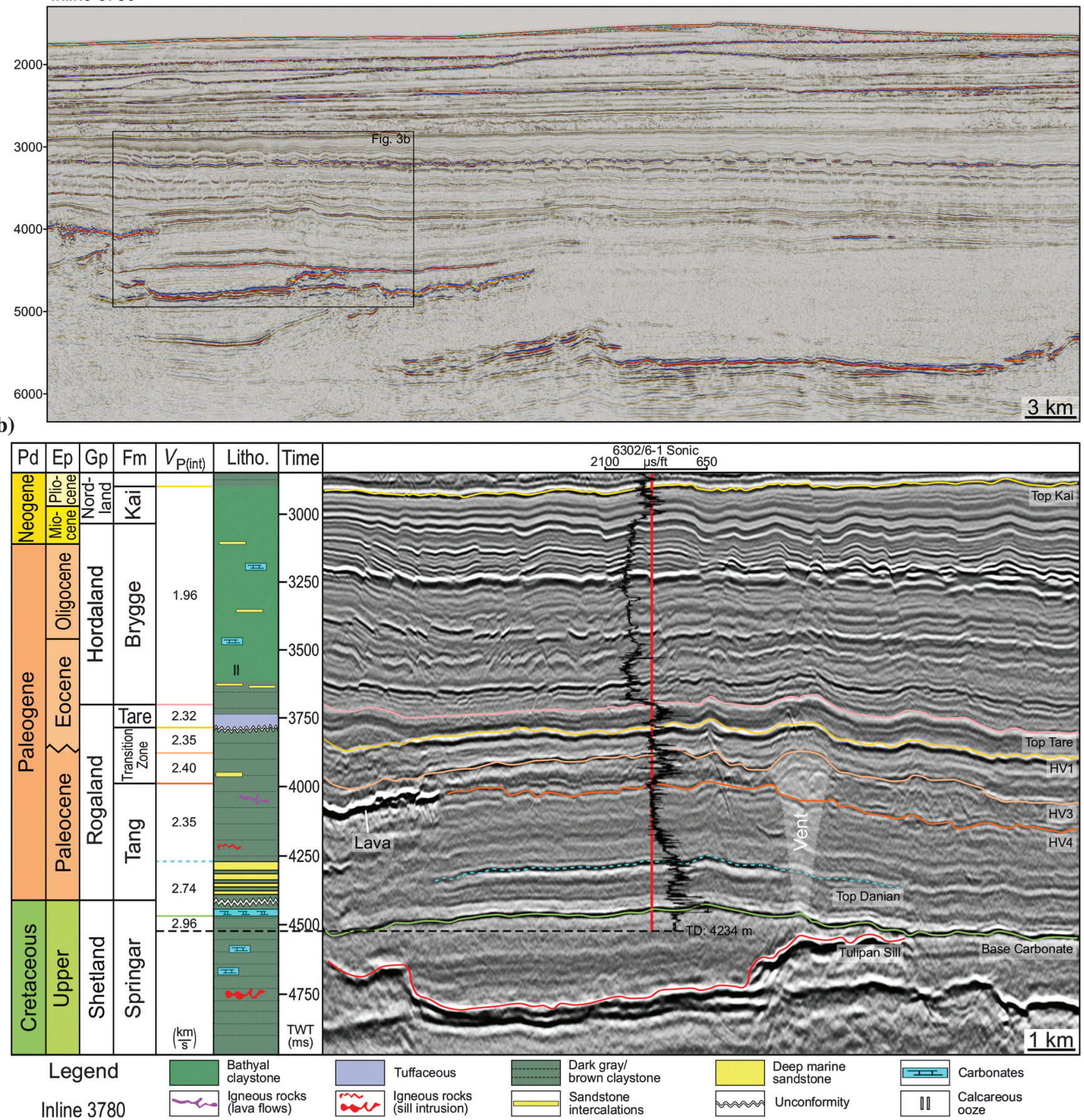

Figure 3. (a) Example of a representative northwest-southeast seismic section. (b) Simplified stratigraphic column of the study area with the principal lithologies encountered in well 6302/6-1. The period (Pd), epoch (Ep), group (Gp), and formation (Fm) are based on the biostratigraphy from cutting samples of well 6302/6-1 (e.g., Kjoberg et al., 2017). Interval velocities $V_{\mathrm{P}_{(i n t)}}$ used in the study derived from the VSP checkshot data. The lithologic column (litho) is based on that of, and described in detail in, Kjoberg et al. (2017). The lithology below the total depth (TD) of the well is an extrapolation. 
the uppermost trough of this reflection package (Figures 5 and 4). We interpreted the top of the sill using guided 2D autotracking, with two-line interval inline/ crossline spacing. The subsequent deeper peak reflection (Figure 5) was roughly picked (16 line interval inline/crossline) as an estimate for the base of the Tulipan sill.

\section{Results \\ Structure of the sill}

Figure 4 shows the 3D expression of the picked highamplitude reflection of the top Tulipan sill, which consists of (1) a flat, strata-concordant inner base with an approximately 10-12 km diameter and (2) flanking in- clined outer sheets that transgress upward and outward (approximately 200-400 ms TWT). Thus, the Tulipan sill displays a typical saucer-shaped geometry. The inclined sheets are laterally segmented radially, with the vertical offset between the segments increasing toward the outer rim (Figure 4).

The base of the Tulipan sill was not clearly observable in the tuned reflection package. The picked base shows lateral thickening of the reflection associated with a reduction in amplitude strength and the interruption of the continuous reflection in the central part of the sill (Figures 5 and 4b). However, because we cannot clearly separate the two reflections for the top and the bottom of the sill, we can only consider the sill thick-

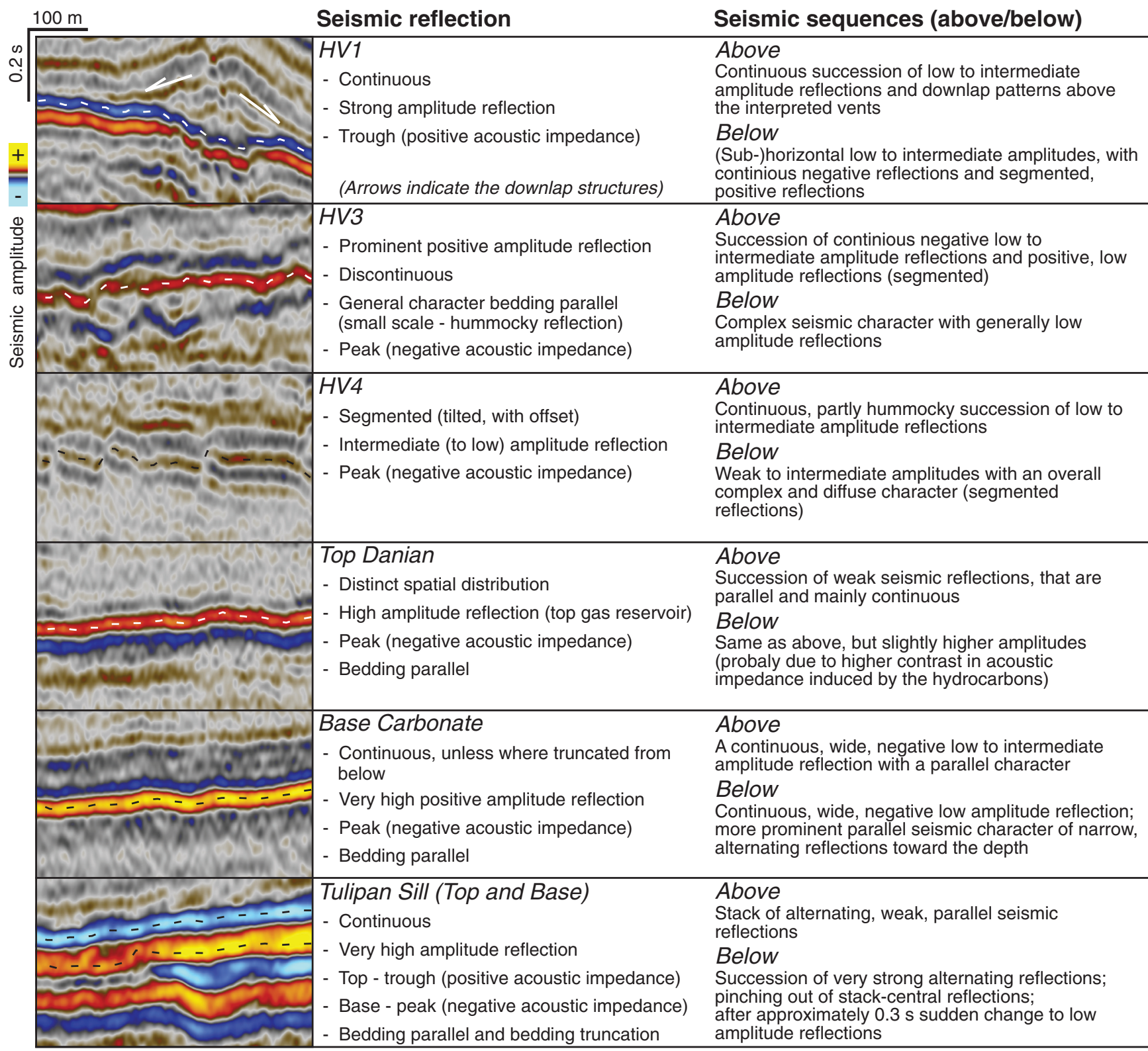

Figure 4. Seismic stratigraphic framework, including a description of the mapped seismic reflections and the seismic sequences they define. 
ness to be between the limit of detection (i.e., $12 \mathrm{~m} \pm 10 \%$ ) and resolution (i.e., $92 \mathrm{~m} \pm 10 \%$ ). This estimate is in agreement with observations of other sills in the Møre and Vøring Basins (e.g., Berndt et al., 2000), as well as those found in outcrop analogs (Eide et al., 2016; Jerram and Bryan, 2017). Using this estimate of thickness and the aerial distribution of the Tulipan sill, its volume is between 1.4 and $13.2 \mathrm{~km}^{3}$. This volume is in the same order as historic flood basalt eruptions; e.g., the Laki eruption with a volume of $14 \mathrm{~km}^{3}$ is one of the largest volume modern eruptions (Bryan et al., 2010).

\section{Structure of the overburden \\ Time-structure maps}

In this study, five key horizons were interpreted in the sedimentary overburden (Figure 5). From the top to the bottom, these are (1) HV1, which describes the top of the deformed overburden locally downlapped by overlying reflections, (2) HV3, a prominent reflection above lavas in the Tang Formation, (3) HV4, a stratigraphic surface that displays a prominent polygonal fault pattern, (4) the Top Danian, which corresponds to the top of the sandstone unit representing the reservoir rock in the area, and (5) the Base Carbonate, a prominent Mesozoic carbonate layer (in the Late Springar Formation; Figures 3 and 5).

HV1 shows a central dome structure that correlates with the periphery of the underlying Tulipan sill (Figure 6a). The maximum amplitude $f$ of this dome structure was calculated, using a best-fitting plane for the estimation of the dome base, to be approximately $f \approx 50 \pm 20 \mathrm{~m}$ (Figure $6 \mathrm{~b}$ ) from the depth-converted timestructure map. Figure 6a shows four additional dome structures surrounding the central dome: (1) one overprinting the outline of the central dome in the northwest and (2) three separate ones in the south and east. A north-south-trending depression separates these three domes from the large central dome above the Tulipan. The underlying time-structure maps of the HV3, HV4, Danian, and Base Carbonate horizons similarly display a large central dome as in HV1 (Figure 6c; Supplemental Figures 1, 2, and 3 can be accessed through the following links: s1.eps, s2.eps, and s3.eps). Note that for the HV3, Top Danian, and Base Carbonate, the data coverage is limited, such that the smaller peripheral domes are not imaged. In addition, the time-structure maps of the different horizons show that the well 6302/6-1 was drilled in the crest of the dome above the Tulipan sill.
Spectral decomposition attribute maps on sedimentary horizons

Spectral decomposition attribute maps were produced on the interpreted horizons in the sedimentary overburden to visualize possible host rock deformations (Figure 7; e.g., fractures, faults, etc.) as well as changes in the lithology.

The attribute map of the uppermost interpreted horizon, HV1, shows 19 dark, subcircular features (white circles; Figure 7a), i.e., structures associated with hydrothermal vent complexes that overlie the lateral termination of the underlying Tulipan sill (e.g., Planke et al., 2005; Berndt et al., 2016). These features correspond to the hydrothermal vent structures mapped by Kjoberg et al. (2017). In plan view on the attribute map, most of these vents can be seen to be connected by thin, linear features (Figure 7a). Similar circular and linear features were observed on HV3 (dashed yellow line; Figure 7b), but they were too faint to be confidently described. A possible spatial correlation of those linear features between the different horizon maps cannot be documented with confidence (Figure $7 \mathrm{a}$ and $7 \mathrm{~b}$ ).

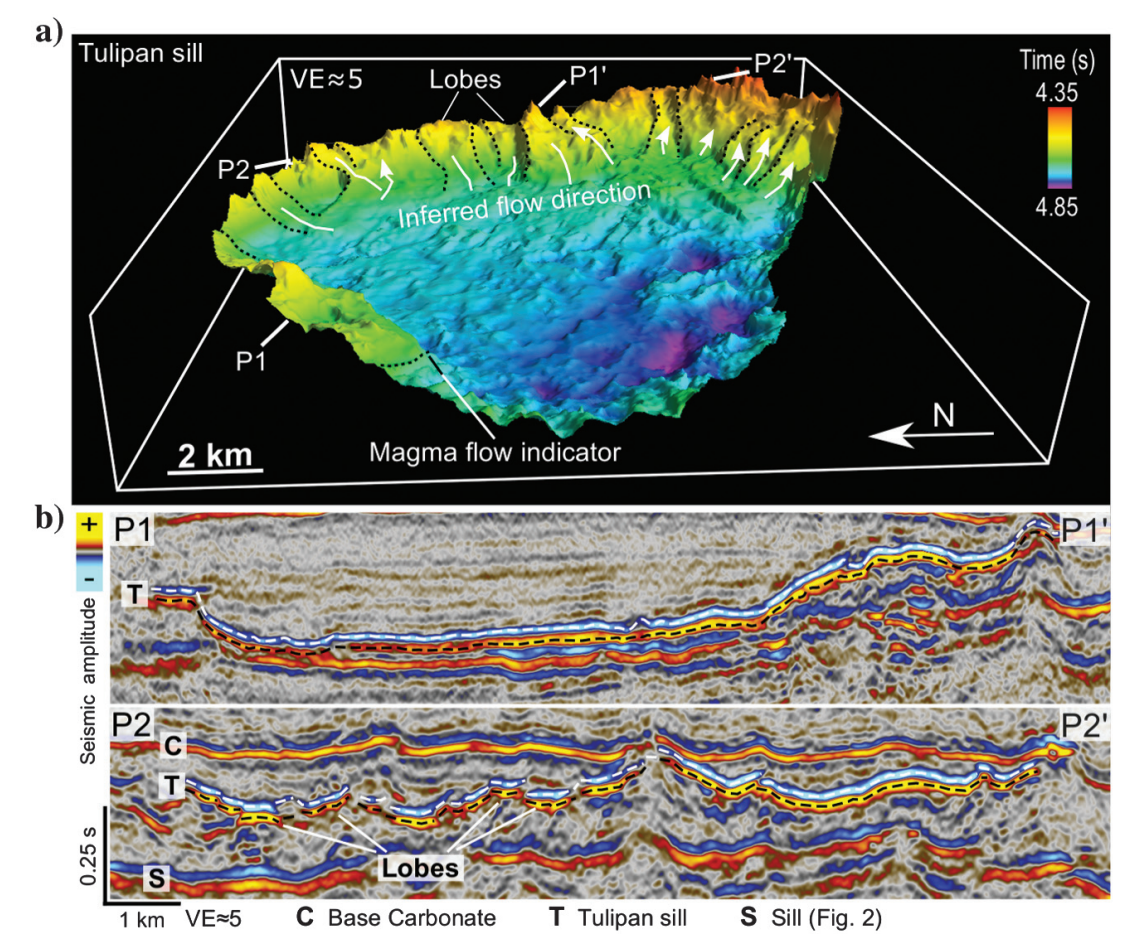

Figure 5. Seismic expression of the Tulipan sill. (a) The $3 \mathrm{D}$ visualization of the saucer-shaped geometry of the top Tulipan sill horizon. Radial magma flow indicators mark edges of reflection segments representing upward, outward transgressing, igneous inclined sheets (Schofield et al., 2012b; Magee et al., 2014), examples of these are highlighted as lobes and cross referenced to profile P2P2' in (b). (b) Seismic profiles show the cross-sectional expressions of the Tulipan sill (see [a] for the location). P1-P1' highlights the picked Tulipan sill top and base, whereas P2-P2' visualizes the segmented character of the Tulipan sill reflection and indicates an underlying sill (S) below the Tulipan sill (Tulipan top — dashed white line; dashed black line tentatively interpreted as the sill base; lobes highlighted in [a] are also indicated). 
a)

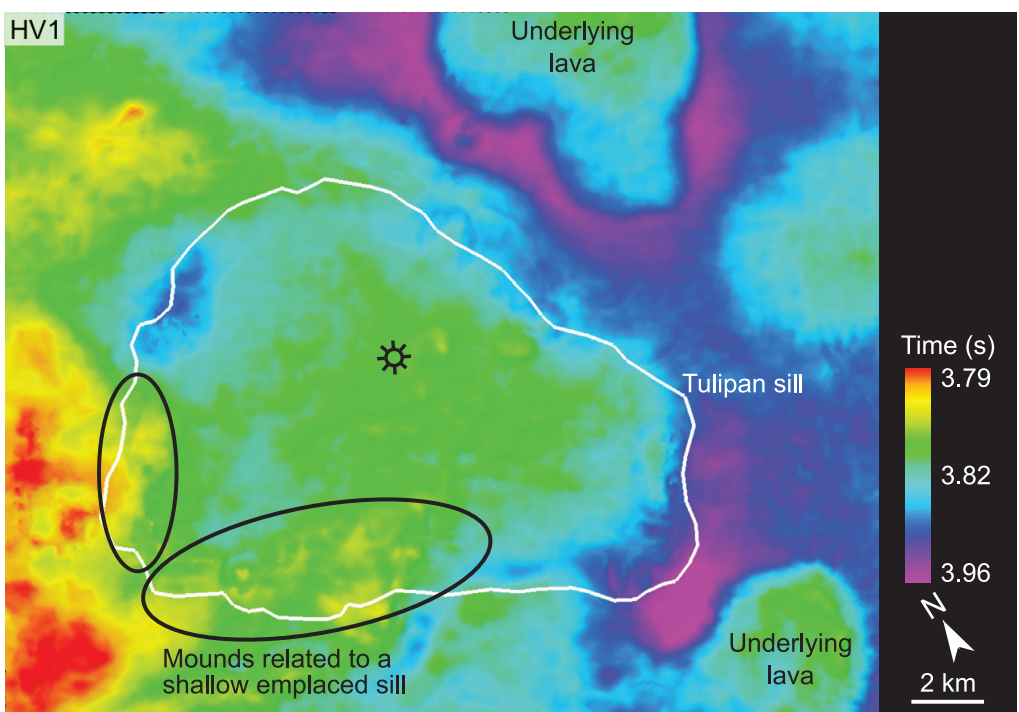

b)

Stack of data points of the HV1 dome

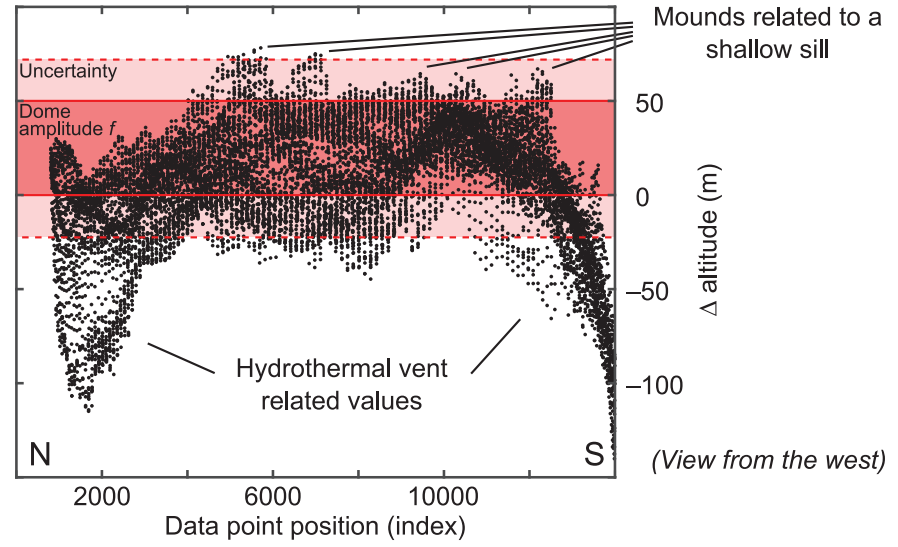

c)

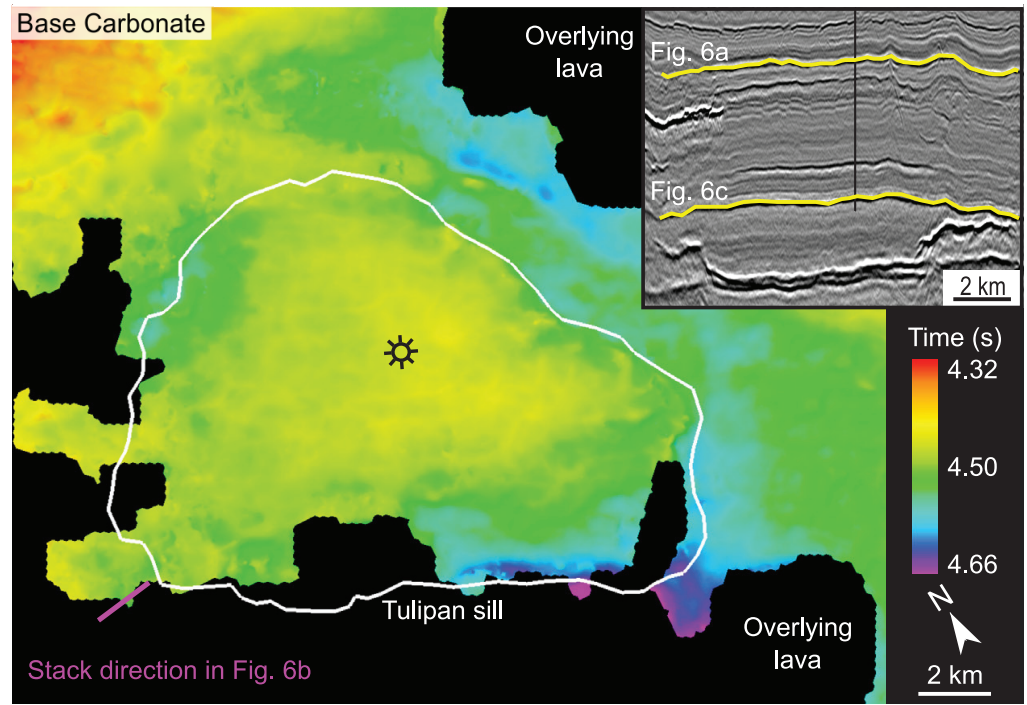

Figure 6. Time-structure maps (TWT) and dome amplitude $f$. (a) The HV1 timestructure map shows the paleo-surface and top of the domed overburden during the emplacement of the Tulipan sill. (b) The stack of altitude data points within the Tulipan periphery highlights the plateau in the domed overburden. A best-fit plane was used to estimate the base of the dome and calculate the amplitude $f$ (red area). (c) Base carbonate time-structure map of the lowermost interpreted horizon above the Tulipan sill shows a good confined dome structure inside the Tulipan sill periphery. Subset shows the stratigraphic location of (a and c).
On the HV3 map (Figure 7b), dark circular features similar to, and at the same locations as those observed in the HV4 map (black ovals; Figure 7c), are present. Note, however, that they are overall larger. They are mainly located along the edge of Tulipan sill, and they correspond to vertical zones characterized by complex and weak seismic reflections crosscutting the horizon (Figure 3). Such features are characteristic of hydrothermal vent complexes (e.g., Svensen et al., 2004; Planke et al., 2005), and they correlate to those identified by Kjoberg et al. (2017). Inside the Tulipan sill periphery, two separate areas can be distinguished: (1) a southern area (dashed yellow line; Figure $7 \mathrm{~b}$ ), which displays dark colors and a complex but faint occurrence of circular features and linear features, and (2) a northern area characterized by bright colors with no observable features (Figure 7b). Outside the Tulipan sill periphery, two comprehensive dark areas in the northwest and northeast are visible (Figure $7 b$ ). We interpret these latter as the extruded Paleogene basalts (Berndt et al., 2001) according to their seismic character (Figures 2 and 3), the emplacement of which was not related to the emplacement of the Tulipan sill and associated doming. Therefore, we will not consider them in the following sections.

The HV4 map highlights an overall coverage with linear features (Figure 7c), which correlate with discontinuities in the seismic reflection data (Figure 5). This polygonal pattern does not display a change in its characteristics inside or outside of the Tulipan periphery (Figure $7 \mathrm{c}$ ). Other observable features are the dark circular patches with diameters up to approximately $1 \mathrm{~km}$ (e.g., black circles; Figure 7c).

The Top Danian horizon attribute map has a very limited spatial distribution inside the periphery of the Tulipan sill (Figures 3 and $7 d$ ). The central part of the horizon map is represented by an area of significantly bright colors, again highlighting lateral variations in rock properties (Figure 7d). No significant feature is visible.

The Base Carbonate horizon (Figure 7e) images the lowermost interpreted reflection in the sedimentary sequence above the Tulipan sill (Figure 3). The 
a)

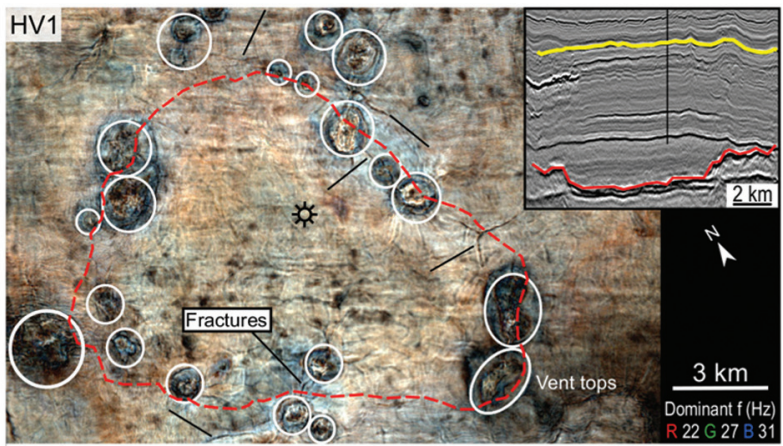

b) $\mathrm{HV} 3$

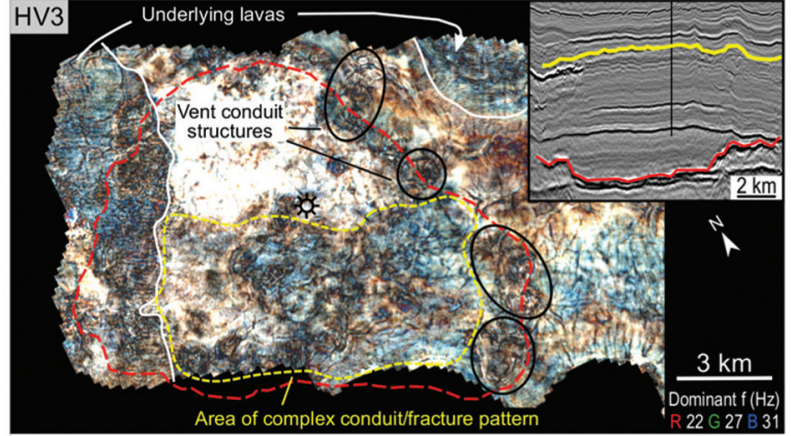

c)

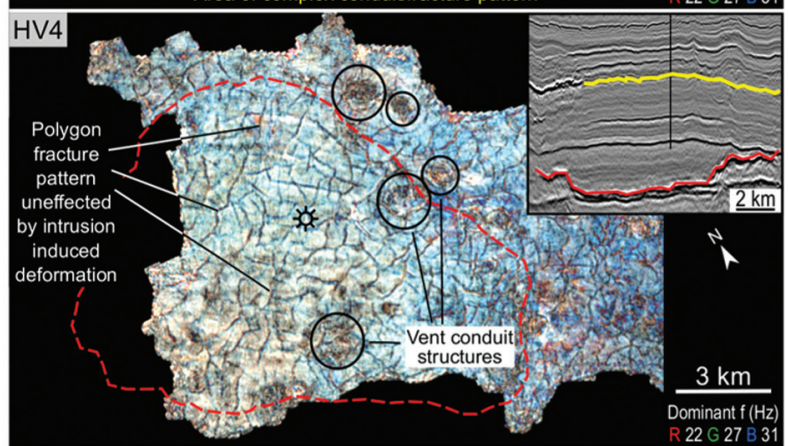

d) Top Danian

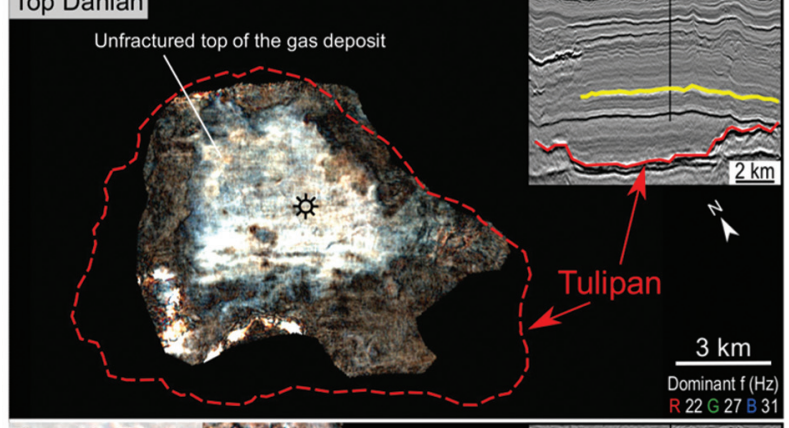

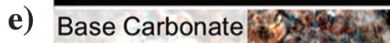

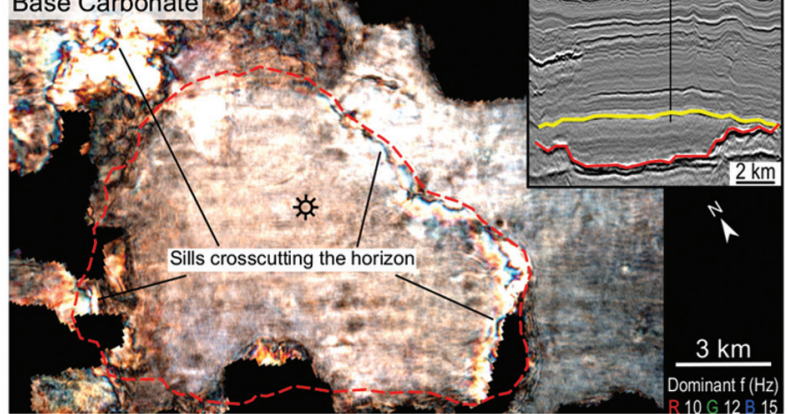

Figure 7. Spectral decomposition attributes maps of key horizons. Subsets display the same seismic section of Figure 3 (for the location, see Figure 2). The periphery of the Tulipan sill (dashed red line) corresponds to the map contour at the level of approximately $4400 \mathrm{~ms}$ (TWT). (a) HV1 (Top Tang Formation) defines the top of the dome structure, and it highlights hydrothermal vent complexes (HTVCs, white circles) and fractures in between (black/ white arrows). (b) The HTVCs on HV3 are obscured by the lava flow pattern (outside the white lines). (c) HV4 envisages a regional polygonal fault system, and deeper parts of the HTVCs (black circles) identified in (a). (d) Top Danian shows no fractures in the top of the reservoir sandstones of the Tulipan prospect. (e) The Base Carbonate shows no evidence for central fractures, but highlights the crosscut of the underlying Tulipan sill (the crosscut itself is not visible in the seismic subset). 
spectral decomposition map shows a distinct dark linefeature corresponding to the crossing of the Tulipan sill though the horizon (Figure 7e). No other prominent feature is visible. Within the Tulipan sill periphery and adjacent to it, an overall bright color scheme is observed, highlighting lateral variations in rock properties.

\section{Isochron maps}

Isochron maps between different horizons were produced to quantify lateral thickness variations of the intervals through the dome above the Tulipan sill (Figures 3 and 8). This information is crucial for testing the different models listed in Figure 1. The 3D seismic data of the Tulipan prospect image a regional thickening of the sedimentary strata toward the west-northwest (Figure 8).

The isochron map of the postemplaced sediments (Top Kai-HV1) in Figure 8a shows that the thickness of younger sediments outside of the Tulipan periphery is larger compared with above the Tulipan sill.

Figure $8 \mathrm{~b}$ displays the isochron map of an interval (Top Tare-HV1). The interpretation of the Top Tare horizon used to produce this isochron map originates from the work of Kjoberg et al. (2017). This interval shows distinct, thick circular mound structures that typically overlie the periphery of the underlying Tulipan sill at the same location as the hydrothermal vent complexes observed before (Figure 7a-7c). The Top TareHV1 interval displays a thinning within the Tulipan periphery compared with the areas in the close vicinity of the underlying sill outline. In addition, we observe fracture pattern between the mound structures and in the surrounding of the sill (Figure $8 \mathrm{~b}$ ) coinciding with the dark linear features observed in Figure $7 \mathrm{a}$.

The HV1-Base Carbonate interval, i.e., the overall sequence analyzed in this study shows a relatively constant thickness, except for localized thinner areas that are parallel to the outline of the underlying sill (Figure 8c). These areas are likely related to hydrothermal vent complexes. However, each subinterval displays more complex patterns.

The preemplacement shallower HV1-HV4 interval exhibits a ring feature, aligned along the periphery of the underlying sill, which presents local subcircular areas with the greatest thickness (Figure 8d). The spatial positions of these local thick areas correspond to the observed dark circular patches in the spectral decomposition attribute maps (Figure 7). These features are likely related to hydrothermal vent complexes (Kjoberg et al., 2017). The thickness of this interval is similar at the center of the underlying sill and outside the sill (Figure 8d).

In contrast to the HV1-HV4 interval, the deeper HV4-Base Carbonate interval exhibits a thickening constrained inside the outline of the Tulipan sill (Figure 8e). Note the prominent thin elongated features parallel to the periphery of the Tulipan sill. These features are not visible on the HV1-HV4 interval (Figure 8d), but they affect the whole studied interval, i.e., HV1-Base Carbonate (Figure 8c). Similarly to the HV4-Base Carbonate interval, the Top Danian-Base Carbonate subinterval also exhibits a thickening (Supplemental Figures 1, 2, and 3 can be accessed through the following links: s1.eps, s2.eps, and s3.eps). The location of this thickening roughly correlates with that of the observed bright colors of the Top Danian spectral decomposition map (Figure 7d).

\section{Interpretation \\ Sill structure and relation with dome}

Our 3D reconstruction of the top Tulipan sill exhibits a characteristic saucer shape, with a flat inner sill, which connects to transgressive inclined sheets ("lobes") that radially increase in vertical offsets (Figure 4). Such a structure is in good agreement with the two-stage model of shallow magma emplacement, whereby an initial flat sill intrudes along a stratigraphic weakness followed by an upward, outward transgressive emplacement of inclined sheets (e.g., Malthe-Sørenssen et al., 2004; Hansen and Cartwright, 2006; Polteau et al., 2008; Thomson and Schofield, 2008; Galland, 2012). The radial offsets visible along the inclined sheets are interpreted as radial flow indicators, i.e., intrusive step and bridge structures indicating upward and outward magma flow during the emplacement into a brittle host rock (e.g., Thomson and Schofield, 2008; Hutton, 2009; Schofield et al., 2010; Magee et al., 2016), also in agreement with the two-stage model of saucer-shaped sill emplacement.

The Tulipan sill exhibits an overall spatial correlation with the overlying dome structure (Figure 6). The well data do not evidence any other sill emplaced in the sill overburden. The seismic data only display a small, shallower sill in the western edge of the dome, resulting only in a local, shallow positive topographic feature (Figure 6; Supplemental Figures 1, 2, and 3 can be accessed through the following links: s1.eps, s2.eps, and s3.eps). Thus, we conclude that the dome displayed in our data is solely related to the underlying Tulipan sill.

The HV1 horizon has been identified as being the paleo-surface at the time of emplacement of the Tulipan sill, based on the detailed interpretation of downlap observed in the 3D seismic associated with the top of the hydrothermal vent complexes related to the edges of the Tulipan sill (Kjoberg et al., 2017). This implies that the Tulipan sill was emplaced between 55.8 and $54.9 \mathrm{Ma}$ (Kjoberg et al., 2017), consistent with the age of the North Atlantic Large Igneous Province emplaced at the Paleocene-Eocene transition (Berndt et al., 2001; Svensen et al., 2004; Faleide et al., 2010). Thus, the depth of emplacement is estimated to be not deeper than $1.5-2 \mathrm{~km}$. The saucer-shaped geometry of the Tulipan sill is a consequence of such a shallow emplacement depth (e.g., Planke et al., 2005; Galland et al., 2009; Eide et al., 2016). This corroborates the observation of other studies (e.g., Hansen et al., 2011; Magee et al., 2014; Eide et al., 2016) and modeling (Galland et al., 2009), in which sills show a more planar geometry with increasing depth of emplacement. 
a)

b)

d)

e)
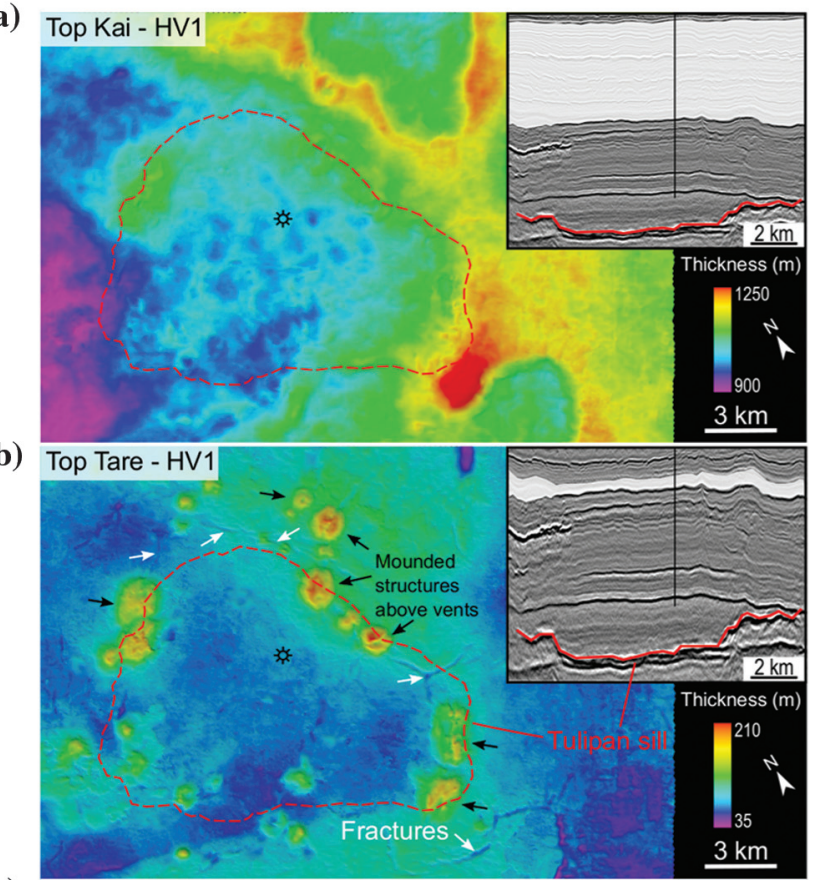

c) HV1 - Base Carbonate
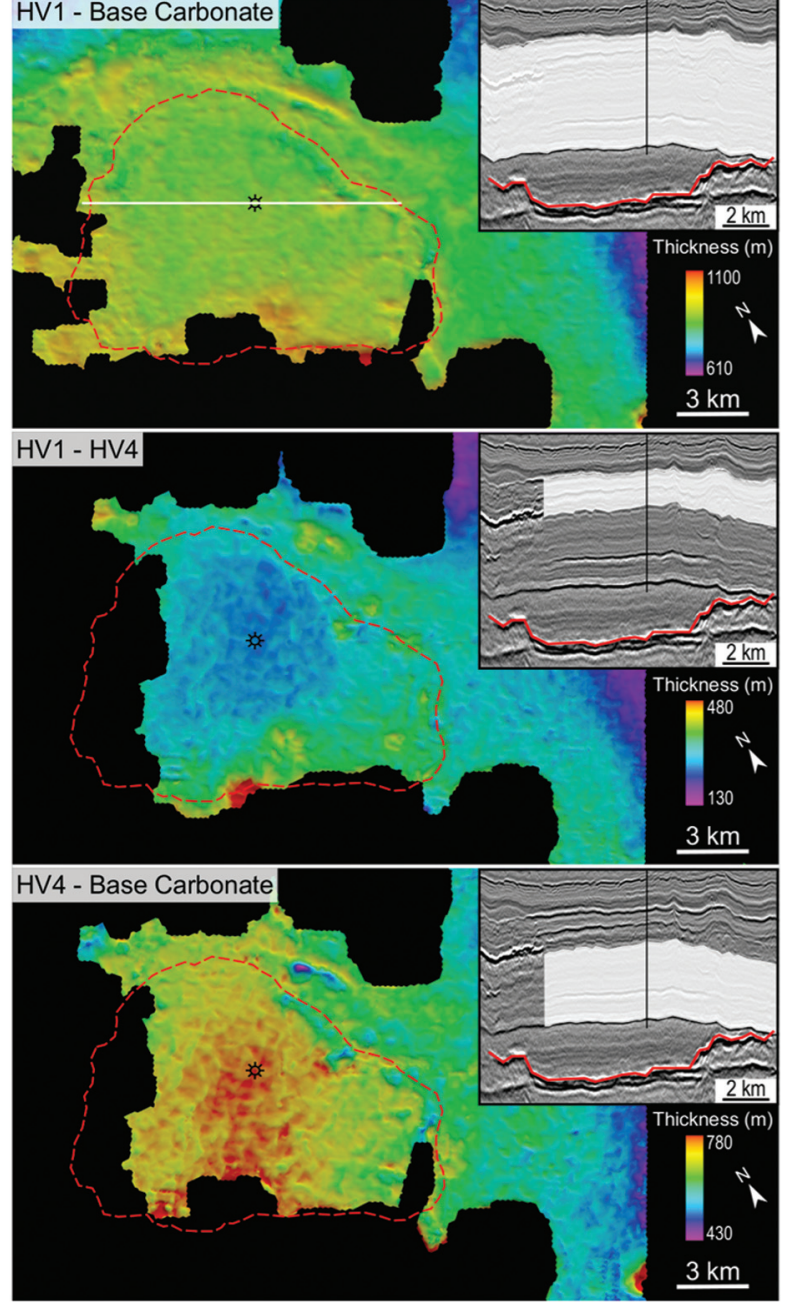

Figure 8. Thickness maps of the sedimentary sequences above the Tulipan sill. (a) Top Kai-HV1 displays the thinner postemplacement sediments above the Tulipan sill compared with the area outside of the Tulipan periphery, resulting from differential compaction. The thin, anomaly in the northwest is caused by several underlying igneous intrusions and the Paleogene Basalts. (b) Top Tare-HV1 isochron map shows the thickness anomalies (i.e., hydrothermal vent complex-related mounds) in sedimentary strata right above the dome structure. (c) Isochron map of the complete strata interpreted (HV1-Base Carbonate). The white line shows the position of the seismic subset. (d) The upper dome structure, i.e., the HV1-HV4 isochron map, shows patchy thickness anomalies (thicker) in the close vicinity of the Tulipan sill periphery, whereas the central area is thin. (e) Isochron map of HV4 to Base Carbonate displays a contrasting thickness variation compared with (d) within the Tulipan sill periphery. 


\section{Dome growth mechanisms}

Our detailed analyses of the borehole and 3D seismic data allow us to test the relevance of the distinct mechanisms of dome growth above igneous sills. Our results highlight the occurrence of post- and synemplacement processes.

\section{Postemplacement differential compaction}

The isochron map of Figure 8a shows that the postemplacement sediments in the Top Kai-HV1 interval are thinner above the Tulipan sill than outside the sill. Postemplacement sediments typically show this greater thickness outside the intrusion periphery than inside when a magmatic intrusion causes folding of the overburden and differential compaction occurs in the sediments above (Hansen and Cartwright, 2006; Jackson et al., 2013). We interpret the occurrence of thicker postemplacement sediments solely on the southeastern side of the Tulipan sill as being related to the other strong reflection events in the $3 \mathrm{D}$ seismic data, i.e., sills and Paleogene basalts (Figures 2, 3, 7, and 8). In addition, isochron maps of Figure 8c and 8e, i.e., the HV1-Base Carbonate interval and the HV4-Base Carbonate subinterval, display similar trends. This thickening is in good agreement with the differential compaction mechanism (Figure 1d). Thus, we conclude that differential compaction must have, at least partly, contributed to the formation of the dome structure above the Tulipan sill. Thus, a key question is whether parts of the dome have resulted from synemplacement mechanisms or not.

\section{Synemplacement mechanisms}

The direct evidence of synemplacement mechanisms of dome growth above the Tulipan sill is limited. We observe fracture patterns located in the vicinity of, and parallel to, the Tulipan sill periphery and dome edge, affecting the paleo-surface horizon HV1 (Figures 7 and 8a). These surficial peripheral concentric tensile/extensional fractures are in good agreement with the laboratory experiments of dome growth of Galland (2012). These experiments show that when a dome associated with an intruding saucer-shaped sill exhibits a plateau shape, like that of the Tulipan dome, the largest convex curvature of the paleo-surface occurs near the upper, monoclinal hinges of the dome (see Figure 1). Thus, the resulting fractures are concentric, parallel, and close to the dome edge (see also Galland et al., 2016). The close relation between these tensile fractures and the hydrothermal vent complexes (Figures 7a and 8a) suggests that the former might have channeled the over-pressurized fluids, and so controlled partly the locations of the vents. Furthermore, the observed central thinning of the shallow interval (HV1-HV4) of the domed sedimentary sequence above the Tulipan sill (Figure 8c) are in good agreement with the observations of Ramsay (1967), who suggests that such thinning might result from outer-arc stretching of the apex of a growing forced fold. The presence of concentric fractures and superficial thinning are the only evidence of forced folding associated with the emplacement of the Tulipan sill.

Other indicators of synemplacement dome growth are not visible. The significant thickness variations of the sedimentary intervals affected by the doming do not solely support the application of the elastic bending model, which assumes constant thickness of the domed formations (e.g., Pollard and Johnson, 1973; Goulty and Schofield, 2008; Galland and Scheibert, 2013). In addition, we do not observe onlap structures on the domed morphology of the paleo-surface, which could confirm the short time scale of an intrusion-induced uplift of the overburden (Figure 1a) (e.g., Trude et al., 2003; Hansen and Cartwright, 2006; Magee et al., 2014). Finally, we do not observe tensile or extensional fractures at the apex of the dome, expected from brittle outer-arc stretching, as observed for instance by Magee et al. (2013). Nevertheless, we cannot rule out that such fractures, if present, are of subseismic scale and so are undetectable. In addition, the observed polygonal fault pattern observable in the whole area (Figure 7c), which formed $57.9 \mathrm{Ma}$ ago prior to the emplacement of the sill of Kjoberg et al. (2017), do not show evidence of reactivation due to forced folding.

In our results, the range of the estimated thickness $t$ of the Tulipan sill and the values of dome amplitude $f$ show a significant overlap. However, due the uncertainties on the sill thickness, this dome amplitude/sill thickness ratio is not conclusive, such that it is not possible to confidently constrain the ratio of contribution of the possible mechanisms for overburden deformation, i.e., elastic bending, differential compaction, and aureole volume reduction.

Our data also highlight the occurrence of hydrothermal vent complexes (Figures 6-8) (see also Kjoberg et al., 2017), which result from local fluidization and gas generation within the host rock (Einsele et al., 1980; Svensen et al., 2004; Schofield et al., 2010, 2012a; Jackson et al., 2013; Aarnes et al., 2015). Nevertheless, these authors show that any fluidization occurs dominantly close to the intrusions, and the resulting structures are likely of subseismic scale and, so, invisible on our seismic data. In addition, the well within the study area is not deep enough to reach the sedimentary rocks near the Tulipan sill; therefore, it is not useful to constrain the thickness of the fluidized rock formations (Figures 3 and $4 \mathrm{~b}$ ). Therefore, our data cannot allow us to constrain to which extent fluidization has accommodated the sill emplacement, and so, the dome growth dynamics.

\section{Conclusion}

Our study uses analysis of 3D seismic and well data to test the occurrence of dome growth dynamics associated with the Tulipan sill. We highlight that a single mechanism cannot explain development of the dome, but rather we show that a combination of different mechanisms controlled the emplacement of the Tulipan sill and its associated deformation of the sedimentary overburden in the Tulipan prospect. We conclude that 
1) The dome displayed in our data is solely related to the underlying Tulipan sill.

2) Our data corroborate the contribution of differential compaction to the formation of the dome structure above the Tulipan sill.

3) Elastic bending had only a minor contribution to the accommodated deformation in the overburden of the Tulipan sill.

4) We infer the formation of dilational fractures in the vicinity and parallel to the Tulipan periphery connecting hydrothermal vent complexes. However, we cannot exclude the fact, that some of the features might be as follows: (1) circumferential tensile fractures at the surface or (2) shear fractures resulting from differential uplift at the dome edge.

5) We cannot confidently observe the process of outerarc stretching, due to missing observations of associated fracture systems in the crest of the domed overburden.

6) Polygonal faults formed prior to the emplacement of the sill do not show evidence of reactivation due to the doming.

Future studies should concentrate on 3D seismic data in combination with well data directly pierced through sills. Where sills are directly intersected by boreholes, direct measurements of their thickness and contact effects can be examined. Such data sets will allow for a more accurate quantitative correlation on the amplitude of the domed overburden compared with the underlying intrusion thickness and will help to constrain the contribution of the different syn- and postemplacement mechanisms of overburden deformation.

\section{Acknowledgments}

We thank Statoil for providing us with the PL251 (Tulipan) geophysical and geologic reports for well 6302/6-1. Thanks to GeoTerric and Schlumberger (Petrel) for the free academic use of seismic software. We further acknowledge the support by the Faculty of Mathematics and Natural Sciences of the University of Oslo and the MIMES project (grant no. 244155) funded by the Petromaks2 program of the Norwegian Research Council. We thank the editor, S. Holford, and the three reviewers (K. Senger and two anonymous) for their constructive comments. Finally, thanks to F. Guldstrand, Ø. T. Haug, and A. Souche for the inspiring discussions.

\section{References}

Aarnes, I., S. Planke, M. Trulsvik, and H. Svensen, 2015, Contact metamorphism and thermogenic gas generation in the Vøring and Møre Basins, offshore Norway, during the Paleocene-Eocene thermal maximum: Journal of the Geological Society, 172, 588-598, doi: 10 .1144/jgs2014-098.

Abdelmalak, M. M., T. B. Andersen, S. Planke, J. I. Faleide, F. Corfu, C. Tegner, G. E. Shephard, D. Zastrozhnov, and R. Myklebust, 2015, The ocean-continent transition in the mid-Norwegian margin: Insight from seismic data and an onshore Caledonian field analogue: Geology, 43, 1011-1014, doi: 10.1130/G37086.1.

Agirrezabala, L. M., 2015, Syndepositional forced folding and related fluid plumbing above a magmatic laccolith: Insights from outcrop (Lower Cretaceous, Basque-Cantabrian Basin, western Pyrenees): Geological Society of America Bulletin, 127, 982-1000, doi: 10.1130/b31192.1.

Bell, B., and H. Butcher, 2002, On the emplacement of sill complexes: Evidence from the Faroe-Shetland Basin: Geological Society, London, Special Publications 197, 307-329.

Berndt, C., C. Hensen, C. Mortera-Gutierrez, S. Sarkar, S. Geilert, M. Schmidt, V. Liebetrau, R. Kipfer, F. Scholz, M. Doll, S. Muff, J. Karstens, S. Planke, S. Petersen, C. Böttner, W.-C. Chi, M. Moser, R. Behrendt, A. Fiskal, M. Lever, C.-C. Su, L. Deng, M. Brennwald, and D. Lizarralde, 2016, Rifting under steam - How rift magmatism triggers methane venting from sedimentary basins: Geology, 44, 767-770, doi: 10.1130/g38049.1.

Berndt, C., S. Planke, E. Alvestad, F. Tsikalas, and T. Rasmussen, 2001, Seismic volcano stratigraphy of the Norwegian Margin: Constraints on tectonomagmatic break-up processes: Journal of the Geological Society, 158, 413-426, doi: 10.1144/jgs.158.3.413.

Berndt, C., O. P. Skogly, S. Planke, O. Eldholm, and R. Mjelde, 2000, High-velocity breakup-related sills in the Vøring Basin, off Norway: Journal of Geophysical Research: Solid Earth, 105, 28443-28454, doi: 10.1029/ 2000JB900217.

Brekke, H., 2000, The tectonic evolution of the Norwegian Sea continental margin with emphasis on the Vøring and Møre Basins: Geological Society, London, Special Publications 167, 327-378.

Bryan, S. E., I. U. Peate, D. W. Peate, S. Self, D. A. Jerram, M. R. Mawby, J. S. Marsh, and J. A. Miller, 2010, The largest volcanic eruptions on earth: Earth-Science Reviews, 102, 207-229, doi: 10.1016/j.earscirev.2010.07.001.

Bunger, A. P., and A. R. Cruden, 2011, Modeling the growth of laccoliths and large mafic sills: Role of magma body forces: Journal of Geophysical Research: Solid Earth, 116, B02203, doi: 10.1029/2010JB007648.

Cartwright, J., and D. M. Hansen, 2006, Magma transport through the crust via interconnected sill complexes: Geology, 34, 929-932, doi: 10.1130/G22758A.1.

Corry, C. E., 1988, Laccoliths: Mechanics of emplacement and growth: Geological Society of America Special Paper, 220, 1-110.

Cosgrove, J. W., and R. D. Hillier, 1999, Forced-fold development within Tertiary sediments of the Alba Field, UKCS: Evidence of differential compaction and postdepositional sandstone remobilization: Geological Society, London, Special Publications 169, 61-71.

Dalland, A., H. O. Augedahl, K. Bomstad, and K. Ofstad, 1988, The Post-Triassic succession of the mid-Norwegian shelf, in A. Dalland, D. Worsley, and K. Ofstad, eds., A lithostratigraphic scheme for the Mesozoic and Cenozoic 
and succession offshore mid-and northern Norway: Norwegian Petroleum Directorate Starvanger, 1-65.

Delpino, D., A. Bermúdez, N. Vitulli, and C. Loscerbo, 2014, Sistema de Petróleo no convencional relacionado con lacolitos Eocenos de intraplaca. Área altiplanicie del Payún, cuenca Neuquina, in Proceedings IX Congreso de Exploración y Desarrollo de Hidrocarburos, Mendoza: Instituto Argentino del Petróleo y el Gas, 223-242.

de Saint-Blanquat, M., G. Habert, E. Horsman, S. S. Morgan, B. Tikoff, P. Launeau, and G. Gleizes, 2006, Mechanisms and duration of non-tectonically assisted magma emplacement in the upper crust: The Black Mesa pluton, Henry Mountains, Utah: Tectonophysics, 428, 1-31, doi: 10.1016/j.tecto.2006.07.014.

Dixon, J. M., and D. G. Simpson, 1987, Centrifuge modeling of laccolith intrusion: Journal of Structural Geology, $\mathbf{9}$, 87-103, doi: 10.1016/0191-8141(87)90046-0.

du Toit, A., 1920, The Karoo dolerites of South Africa: A study in hypabyssal injection: Transactions of the Geological Society of South Africa, 23, 1-42.

Eide, C. H., N. Schofield, D. A. Jerram, and J. A. Howell, 2016, Basin-scale architecture of deeply emplaced sill complexes: Jameson Land, East Greenland: Journal of the Geological Society, 174, 23-40, doi: 10.1144/ jgs2016-018.

Einsele, G., J. M. Gieskes, J. Curray, D. M. Moore, E. Aguayo, M.-P. Aubry, D. Fornari, J. Guerrero, M. Kastner, K. Kelts, M. Lyle, Y. Matoba, A. Molina-Cruz, J. Niemitz, J. Rueda, A. Saunders, H. Schrader, B. Simoneit, and V. Vacquier, 1980, Intrusion of basaltic sills into highly porous sediments, and resulting hydrothermal activity: Nature, $\mathbf{2 8 3}$, 441-445, doi: 10.1038/283441a0.

Faleide, J. I., K. Bjørlykke, and R. H. Gabrielsen, 2010, Geology of the Norwegian continental shelf, petroleum geoscience: Springer, 467-499.

Galerne, C. Y., O. Galland, E.-R. Neumann, and S. Planke, 2011, 3D relationships between sills and their feeders: Evidence from the Golden Valley Sill Complex (Karoo Basin) and experimental modeling: Journal of Volcanology and Geothermal Research, 202, 189-199, doi: 10 .1016/j.jvolgeores.2011.02.006.

Galland, O., 2012, Experimental modeling of ground deformation associated with shallow magma intrusions: Earth and Planetary Science Letters, 317-318, 145-156, doi: 10 .1016/j.epsl.2011.10.017.

Galland, O., H. S. Bertelsen, F. Guldstrand, L. Girod, R. F. Johannessen, F. Bjugger, S. Burchardt, and K. Mair, 2016, Application of open-source photogrammetric software MicMac for monitoring surface deformation in laboratory models: Journal of Geophysical Research: Solid Earth, 121, 2852-2872, doi: 10.1002/2015JB012564.

Galland, O., S. Burchardt, E. Hallot, R. Mourgues, and C. Bulois, 2014, Dynamics of dikes versus cone sheets in volcanic systems: Journal of Geophysical Research: Solid Earth, 119, 6178-6192, doi: 10.1002/2014JB011059.
Galland, O., E. Holohan, B. van Wyk de Vries, and S. Burchardt, 2015, Laboratory modeling of volcano plumbing systems: A review, in C. Breitkreuz and S. Rocchi, eds., Advances in volcanology: Springer, 1-68.

Galland, O., S. Planke, E.-R. Neumann, and A. MaltheSørenssen, 2009, Experimental modeling of shallow magma emplacement: Application to saucer-shaped intrusions: Earth and Planetary Science Letters, 277, 373383, doi: 10.1016/j.epsl.2008.11.003.

Galland, O., and J. Scheibert, 2013, Analytical model of surface uplift above axisymmetric flat-lying magma intrusions: Implications for sill emplacement and geodesy: Journal of Volcanology and Geothermal Research, 253, 114-130, doi: 10.1016/j.jvolgeores.2012.12.006.

Gilbert, G. K., 1877, Report on the geology of the Henry Mountains, Washington: U. S. Geographical Geological Survey of the Rocky Mountain, Region.

Goulty, N. R., and N. Schofield, 2008, Implications of simple flexure theory for the formation of saucer-shaped sills: Journal of Structural Geology, 30, 812-817, doi: 10.1016/j.jsg.2008.04.002.

Hansen, D. M., and J. Cartwright, 2006, The three-dimensional geometry and growth of forced folds above saucer-shaped igneous sills: Journal of Structural Geology, 28, 1520-1535, doi: 10.1016/j.jsg.2006.04.004.

Hansen, J., D. A. Jerram, K. McCaffrey, and S. R. Passey, 2011, Early Cenozoic saucer-shaped sills of the Faroe Islands: An example of intrusive styles in basaltic lava piles: Journal of the Geological Society, 168, 159-178, doi: 10.1144/0016-76492010-012.

Hutton, D., 2009, Insights into magmatism in volcanic margins: Bridge structures and a new mechanism of basic sill emplacement - Theron Mountains, Antarctica: Petroleum Geoscience, 15, 269-278, doi: 10.1144/ 1354-079309-841.

Jackson, C. A.-L., N. Schofield, and B. Golenkov, 2013, Geometry and controls on the development of igneous sill-related forced folds: A 2-D seismic reflection case study from offshore southern Australia: Geological Society of America Bulletin, 125, 1874-1890, doi: 10.1130/ B30833.1.

Jerram, D. A., and S. E. Bryan, 2017, Plumbing systems of shallow level intrusive complexes, in C. Breitkreuz and S. Rocchi, eds., Advances in volcanology: Springer, 1-22.

Kavanagh, J. L., T. Menand, and R. S. J. Sparks, 2006, An experimental investigation of sill formation and propagation in layered elastic media: Earth and Planetary Science Letters, 245, 799-813, doi: 10.1016/j.epsl.2006.03.025.

Kay, S. M., O. Mancilla, and P. Copeland, 2006, Evolution of the late Miocene Chachahuén volcanic complex at $37^{\circ} \mathrm{S}$ over a transient shallow subduction zone under the Neuquén Andes: Geological Society of America Special Papers, 407, 215-246, doi: 10.1130/2006.2407(10).

Kjoberg, S., T. Schmiedel, S. Planke, H. Svensen, J. Millett, D. A. Jerram, O. Galland, I. Lecomte, N. Schofield, Ø. T. Haug, and A. Heslem, 2017, 3D structure and formation 
of hydrothermal vent complexes at the PaleoceneEocene transition, the Møre Basin, mid-Norwegian Margin: Interpretation, 5, this issue, doi: 10.1190/int-20160159.1.

Kontorovich, A. E., A. V. Khomenko, L. M. Burshtein, I. I. Likhanov, A. L. Pavlov, V. S. Staroseltsev, and A. A. Ten, 1997, Intense basic magmatism in the Tunguska petroleum basin, eastern Siberia, Russia: Petroleum Geoscience, 3, 359-369, doi: 10.1144/petgeo.3.4.359.

Magee, C., F. Briggs, and C. A. L. Jackson, 2013, Lithological controls on igneous intrusion-induced ground deformation: Journal of the Geological Society, 170, 853-856, doi: 10.1144/jgs2013-029.

Magee, C., C. A.-L. Jackson, and N. Schofield, 2014, Diachronous sub-volcanic intrusion along deep-water margins: Insights from the Irish Rockall Basin: Basin Research, 26, 85-105, doi: 10.1111/bre.2014.26.issue-1.

Magee, C., S. M. Maharaj, T. Wrona, and C. A.-L. Jackson, 2015, Controls on the expression of igneous intrusions in seismic reflection data: Geosphere, 11, 1024-1041, doi: $10.1130 / \mathrm{GES} 01150.1$.

Magee, C., J. D. Muirhead, A. Karvelas, S. P. Holford, C. A. L. Jackson, I. D. Bastow, N. Schofield, C. T. E. Stevenson, C. McLean, and W. McCarthy, 2016, Lateral magma flow in mafic sill complexes: Geosphere, 12, 809-841, doi: 10.1130/GES01256.1.

Malthe-Sørenssen, A., S. Planke, H. Svensen, and B. Jamtveit, 2004, Formation of saucer-shaped sills: Geological Society, London, Special Publications 234, 215-227.

Menand, T., 2008, The mechanics and dynamics of sills in layered elastic rocks and their implications for the growth of laccoliths and other igneous complexes: Earth and Planetary Science Letters, 267, 93-99, doi: 10.1016/j .epsl.2007.11.043.

Morgan, S., A. Stanik, E. Horsman, B. Tikoff, M. de Saint Blanquat, and G. Habert, 2008, Emplacement of multiple magma sheets and wall rock deformation: Trachyte Mesa intrusion, Henry Mountains, Utah: Journal of Structural Geology, 30, 491-512, doi: 10.1016/j.jsg.2008.01.005.

Planke, S., T. Rasmussen, S. S. Rey, and R. Myklebust, 2005, Seismic characteristics and distribution of volcanic intrusions and hydrothermal vent complexes in the Vøring and Møre Basins: Geological Society, London, Petroleum Geology Conference Series 6, 833-844.

Planke, S., H. Svensen, R. Myklebust, S. Bannister, B. Manton, and L. Lorenz, 2015, Geophysics and remote sensing, in C. Breitkreuz and S. Rocchi, eds., Advances in volcanology: Springer, 1-16.

Planke, S., P. A. Symonds, E. Alvestad, and J. Skogseid, 2000, Seismic volcanostratigraphy of large-volume basaltic extrusive complexes on rifted margins: Journal of Geophysical Research: Solid Earth, 105, 19335-19351, doi: 10.1029/1999JB900005.

Pollard, D. D., and A. M. Johnson, 1973, Mechanics of growth of some laccolithic intrusions in the Henry mountains, Utah. II: Bending and failure of overburden layers and sill formation: Tectonophysics, 18, 311-354, doi: 10.1016/0040-1951(73)90051-6.

Polteau, S., A. Mazzini, O. Galland, S. Planke, and A. Malthe-Sørenssen, 2008, Saucer-shaped intrusions: Occurrences, emplacement, and implications: Earth and Planetary Science Letters, 266, 195-204, doi: 10.1016/ j.epsl.2007.11.015.

Potter, J., and J. Konnerup-Madsen, 2003, A review of the occurrence and origin of a biogenic hydrocarbons in igneous rocks: Hydrocarbons in Crystalline Rocks, 214, 151-173, doi doi: 10.1144/GSL.SP.2003.214.01.10.

Ramsay, J. G., 1967, Folding and fracturing of rocks: McGraw-Hill Companies.

Rodriguez Monreal, F., H. J. Villar, R. Baudino, D. Delpino, and S. Zencich, 2009, Modeling an atypical petroleum system: A case study of hydrocarbon generation, migration and accumulation related to igneous intrusions in the Neuquen Basin, Argentina: Marine and Petroleum Geology, 26, 590-605, doi: 10.1016/j.marpetgeo.2009.01.005.

Roman-Berdiel, T., D. Gapais, and J. P. Brun, 1995, Analogue models of laccolith formation: Journal of Structural Geology, 17, 1337-1346, doi: 10.1016/0191-8141(95)00012-3.

Schofield, N., I. Alsop, J. Warren, J. R. Underhill, R. Lehné, W. Beer, and V. Lukas, 2014, Mobilizing salt: Magma-salt interactions: Geology, 42, 599-602, doi: 10.1130/G35406.1.

Schofield, N., L. Heaton, S. P. Holford, S. G. Archer, C. A.-L. Jackson, and D. W. Jolley, 2012b, Seismic imaging of 'broken bridges': Linking seismic to outcrop-scale investigations of intrusive magma lobes: Journal of the Geological Society, 169, 421-426, doi: 10.1144/0016-76492011-150.

Schofield, N., D. J. Brown, C. Magee, and C. T. Stevenson, 2012a, Sill morphology and comparison of brittle and non-brittle emplacement mechanisms: Journal of the Geological Society, 169, 127-141, doi: 10.1144/001676492011-078.

Schofield, N., S. Holford, J. Millett, D. Brown, D. Jolley, S. R. Passey, D. Muirhead, C. Grove, C. Magee, J. Murray, M. Hole, C. A.-L. Jackson, and C. Stevenson, 2015, Regional magma plumbing and emplacement mechanisms of the Faroe-Shetland Sill Complex: implications for magma transport and petroleum systems within sedimentary basins: Basin Research, 29, 41-63, doi: 10.1111/bre .12164.

Schofield, N., C. Stevenson, and T. Reston, 2010, Magma fingers and host rock fluidization in the emplacement of sills: Geology, 38, 63-66, doi: 10.1130/G30142.1.

Schutter, S. R., 2003a, Hydrocarbon occurrence and exploration in and around igneous rocks: Geological Society, London, Special Publications 214, 7-33.

Schutter, S. R., 2003b, Occurrences of hydrocarbons in and around igneous rocks: Geological Society, London, Special Publications 214, 35-68.

Senger, K., S. J. Buckley, L. Chevallier, Å. Fagereng, O. Galland, T. H. Kurz, K. Ogata, S. Planke, and J. Tveranger, 2015, Fracturing of doleritic intrusions and associated contact zones: Implications for fluid flow in volcanic ba- 
sins: Journal of African Earth Sciences, 102, 70-85, doi: 10.1016/j.jafrearsci.2014.10.019.

Senger, K., J. Millett, S. Planke, K. Ogata, C. Eide, M. Festøy, O. Galland, and D. A. Jerram, forthcoming, Effects of igneous intrusions on the petroleum system: A review: First Break.

Smallwood, J. R., and J. Maresh, 2002, The properties, morphology and distribution of igneous sills: Modeling, borehole data and 3D seismic from the Faroe-Shetland area: Geological Society, London, Special Publications 197, 271-306.

Stearns, D. W., 1978, Faulting and forced folding in the Rocky Mountains foreland: Geological Society of America Memoirs, 151, 1-38, doi: 10.1130/MEM151.

Svensen, H., F. Corfu, S. Polteau, Ø. Hammer, and S. Planke, 2012, Rapid magma emplacement in the Karoo Large Igneous Province: Earth and Planetary Science Letters, 325-326, 1-9, doi: 10.1016/j.epsl.2012.01.015.

Svensen, H., S. Planke, A. Malthe-Sørenssen, B. Jamtveit, R. Myklebust, T. Rasmussen Eidem, and S. S. Rey, 2004, Release of methane from a volcanic basin as a mechanism for initial Eocene global warming: Nature, 429, 542-545, doi: 10.1038/nature02566.

Thomson, K., and D. Hutton, 2004, Geometry and growth of sill complexes: Insights using 3D seismic from the North Rockall Trough: Bulletin of Volcanology, 66, 364-375, doi: 10.1007/s00445-003-0320-z.
Thomson, K., and N. Schofield, 2008, Lithological and structural controls on the emplacement and morphology of sills in sedimentary basins: Geological Society, London, Special Publications 302, 31-44.

Timoshenko, S. P., and S. Woinowsky-Krieger, 1959, Theory of plates and shells: McGraw-Hill Book Company.

Trude, J., J. Cartwright, R. J. Davies, and J. R. Smallwood, 2003, New technique for dating igneous sills: Geology, 31, 813-816, doi: 10.1130/G19559.1.

Wilson, P. I. R., K. J. W. McCaffrey, R. W. Wilson, I. Jarvis, and R. E. Holdsworth, 2016, Deformation structures associated with the Trachyte Mesa intrusion, Henry Mountains, Utah: Implications for sill and laccolith emplacement mechanisms: Journal of Structural Geology, 87, 30-46, doi: 10.1016/j.jsg.2016.04.001.

Witte, J., M. Bonora, C. Carbone, and O. Oncken, 2012, Fracture evolution in oil-producing sills of the Rio Grande Valley, northern Neuquen Basin, Argentina: AAPG Bulletin, 96, 1253-1277, doi: 10.1306/10181110152.

Zhao, F., S. Wu, Q. Sun, M. Huuse, W. Li, and Z. Wang, 2014, Submarine volcanic mounds in the Pearl River Mouth Basin, northern South China Sea: Marine Geology, 355, 162-172, doi: 10.1016/j.margeo.2014.05.018.

Biographies and photographs of the authors are not available. 